\title{
Impact of a Longwave UV-B Radiation on Soybean Plants Grown at Increased Nickel Concentration in Soil
}

\author{
Elżbieta Skórska ${ }^{1 *}$, Renata Matuszak-Slamani' ${ }^{1}$, Hubert Romanowski², Wiktor Szwarc \\ 1 Department of Physics and Agrophysics, West Pomeranian University of Technology, Papieża Pawła VI no 3, \\ 71-459 Szczecin, Poland \\ 2 Department of Landscape Architecture; West Pomeranian University of Technology, Słowackiego 17, 71-454 \\ Szczecin, Poland \\ * Corresponding author's e-mail: skorska@zut.edu.pl
}

\begin{abstract}
Plants of soybean (Glycine max L.) cv. Augusta grew in the soil with addition of Ni in the concentration of 80 (C-80) or $120 \mathrm{mg} \cdot \mathrm{kg}^{-1}$ dry mass (C-120) or without $\mathrm{Ni}(\mathrm{C}-0)$, and they were subjected to UV-B (300 nm $\left.-315 \mathrm{~nm}\right)$ dose of $1.8 \mathrm{~kJ} \mathrm{~m}^{-2} \mathrm{~d}^{-1}$ for 28 days. The addition of nickel into soil in the concentration of $120 \mathrm{mg} \mathrm{kg}^{-1}(\mathrm{C}-120)$ caused a decrease of the plant height by $35 \%$ compared to the control $(\mathrm{C}-0)$, and in the presence of UV-B (U-120) - by $43 \%$. The shoot fresh and dry mass in the C-80 and C-120 plants were lower by $33 \%$ and $52 \%$ than in the $\mathrm{C}-0$. In the presence of $\mathrm{Ni}$, the intensity of net photosynthesis decreased by $55 \%$. UV-B caused an increase of flavonoid content by $25 \%$ compared to the control (C-0), and $\mathrm{Ni}$ induced a reduction in the content of these compounds from $20 \%$ to $40 \%$.
\end{abstract}

Keywords: chlorophyll fluorescence, flavonoids, Glycine max, photosynthesis, ultraviolet B

\section{INTRODUCTION}

Contamination of soil with heavy metals usually results in an increase in their content in the roots and leaves of plants. It depends on the type of metal and the form of the chemical compound, as well as the plant species (Kabata-Pendias and Pendias, 2001). In recent decades, nickel (Ni) has generated more and more interest from researchers, as in contaminated soils its concentration has reached 26,000 $\mathrm{mg} \mathrm{kg}^{-1}$, i.e. 20-30 times higher concentration than in the non-contaminated areas. The nickel toxicity to plants is becoming a global problem threatening sustainable agriculture. The level of of Ni toxicity is greater than $10 \mathrm{mg} \mathrm{kg}^{-1}$ of dry mass (DM) for sensitive species (Kozlov, 2005), > $50 \mathrm{mg} \mathrm{kg}^{-1} \mathrm{DM}$ in moderately tolerant species and $>1,000 \mathrm{mg} \mathrm{kg}^{-1} \mathrm{DM}$ in Ni hyper accumulator plants such as Alyssum and Thalspi species (Yusuf et al., 2011). Nickel belongs to essential trace micronutrients and its natural content in plants varies between $0.1 \mathrm{mg} \mathrm{kg}^{-1}-1 \mathrm{mg} \mathrm{kg}^{-1}$ of plant dry matter (Meindl et al., 2014). It is an element that is easily absorbed by plants, and in excessive amounts limits the growth and disrupts physiological and metabolic processes, but its phytotoxicity depends on the plant species, the variety and its concentration in the soil, as well as on the chemical form in which the element is bound in the soil (Molas and Baran 2004; Kutman et al., 2014). Among the unfavourable symptoms of the effects of $\mathrm{Ni}$, inhibition of elongation growth, reduction of leaf area, symptoms of chlorosis and necrosis as well as inhibition of photosynthesis, resulting in a reduction in crop yield, were observed (Guo et al., 2010).

As a result of the anthropogenic activity, with the exception of heavy metals, the release of chlorofluorocarbons (CFCs), methane, nitrogen oxide, and other hazardous gases into the atmosphere caused a decrease in the concentration of stratospheric ozone, which is a natural protective barrier against solar ultraviolet radiation, reaching the surface of the Earth (UNEP, 2016). This leads to an increase in the amount of UV-B 
$(280 \mathrm{~nm}-315 \mathrm{~nm})$ that reaches the earth surface. Plants are exposed to the damage caused by this environmental factor, because they contain many cellular components such as nucleic acids, proteins, lipids, and quinones that can absorb the UV-B radiation directly. It often causes a reduction in height, leaf area, biomass accumulation, disturbance of photosynthesis and many other metabolic processes, reduction of chlorophyll content, changes in antioxidant enzyme activity (Bandurska et al., 2013; Hideg et al., 2013; Bornman et al., 2015). The effect of increased UV-B radiation on a growth and development of plants can be modified by abiotic factors such as elevated or reduced temperature, water deficiency, increased concentration of $\mathrm{CO}_{2}$ or ozone, as well as heavy metals (Prasad et al., 2005; Li et al., 2012; Srivastava et al., 2012). From this point of view, the study on the simultaneous effects of $\mathrm{Ni}$ and UV-B is very important for obtaining a significant and realistic picture of current environmental changes. Soybean chosen for our experiment is a good and cheap source of valuable protein. The aim of the study was to examine the effect of increased UV-B radiation and increased nickel content in soil, applied separately and in combination, on plant height and shoot mass, photosynthesis process, chlorophyll and flavonoids content as well as the antioxidant enzyme activity in young soybean plants, Polish variety named Augusta.

\section{MATERIAL AND METHODS}

Soybean plants (Glycine max L.) cv. Augusta cultivated in the greenhouse in the spring (May-July), in pots divided into three groups differing in the concentration of nickel in the soil substrate: 0,80 or $120 \mathrm{mg} \mathrm{kg}^{-1} \mathrm{DM}$. Each group consisted of 24 plants. During the entire experiment, the plants were watered regularly every two to three days with Hoagland solution. Each of the three groups of pots with plants was divided into two variants marked accordingly +UV-B and UV-B and placed on a trolley in a greenhouse. The plants of the first variant were treated with UV-B, starting from the phase of the first pair of (specific leaves developed), i.e. 11 on a $\mathrm{BBCH}$ scale (Meier, 2001). Plant irradiation time was 6 hours a day using TL 100/01 Philips lamps (Eindhoven, The Netherlands), emitting UV-B radiation only in a narrow band $305 \mathrm{~nm}-320 \mathrm{~nm}$ (Skórska, 2000), the value of biologically effective dose of UV-B ${ }_{B E}$ radiation was $1.7 \mathrm{~kJ} \mathrm{~m}^{-2} \mathrm{~d}^{-1}$. The measurements of UV radiation intensity were carried out using the IL 1400 radiometer (International Light Inc., USA) with the detector SEL 240/UV-B1/W. The emission spectrum of the used lamps was recorded by means of the HR 2000 spectroradiometer controlled by the Spectrasuite program (Ocean Optics, USA). The control group, marked as C-0, consisted of the plants that were not exposed to any of two factors. The intensity of photosynthetic active radiation (PAR) with a wavelength in the range of $400 \mathrm{~nm}-700 \mathrm{~nm}$ measured with the FF-01 phytophotometer (Sonopan, Bialystok) was about $700 \mu \mathrm{mol}$ PPFD m $\mathrm{m}^{-2} \mathrm{~s}^{-1}$ at noon. When the plants were in the development phase 51 on the BBCH scale - the first flower buds were visible, measurements of the plant height and fresh mass of aboveground parts (shoots with leaves) for 10 plants in each variant were taken. The dry mass was determined after drying of the aboveground parts at $105^{\circ} \mathrm{C}$ for 24 hours. The SPAD 502 Chlorophyll Meter (Minolta, Japan) was used to determine the greenness index expressed in SPAD units; 1 SPAD corresponds to the chlorophyll content of approximately $0.08 \mathrm{mg} \mathrm{dm}^{-2}$ of the soybean leaf area. The content of compounds absorbing UV-B radiation, mainly flavonoids, was determined as the absorbance value of leaf ethanol extracts at $305 \mathrm{~nm}$ per $1 \mathrm{~g}$ of dry mass, $\mathrm{A}_{305} \mathrm{~g}^{-1}$ (Skórska, 2000). The measurements of net photosynthesis rate $\left(\mathrm{P}_{\mathrm{N}}, \mu \mathrm{mol} \mathrm{CO} \mathrm{m}^{-2} \mathrm{~s}^{-1}\right)$ and water transpiration intensity $\left(\mathrm{E}, \mathrm{mmol} \mathrm{H}_{2} \mathrm{O} \mathrm{m}^{-2} \mathrm{~s}^{-1}\right)$ in the leaves of the plants studied were made using a LCA-4 gas analyzer (ADC Ltd, UK) with a PLC4 camera and LED illuminator emitting red light (PPFD $800 \mu \mathrm{mol} \mathrm{m}^{-2} \mathrm{~s}^{-1}$ ). In the measuring camera, one leaf of a few soybean plants growing in pots was placed successively (leaves were selected from the same floor of randomly selected plants from particular variants). The peroxidase (PRX) and catalase (CAT) activity were analysed as described Skórska (2000), using a Specord UV-VIS M 42 spectrophotometer. Chlorophyll fluorescence measured by means of a portable PAM-200 Chlorophyll Fluorometer (Heinz Walz GmbH, Germany) was described by Skórska and Murkowski (2012). The results were presented as means (5-10 biological independent repetitions) \pm standard deviation, excluding fresh and dry mass, which was determined for all 10 plants, and divided per one plant. On the basis of a two-factor analysis of variance (Ni concentration, UV-B radiation) conducted with the Statistica 13 software 
(StatSoft Polska) homogeneous groups were determined at the significance level of $p<0.05$ (Newman-Keuls test); the mean values belonging to the same group were designated with the same letters.

\section{RESULTS}

In the case of the non-irradiated soybean plants, the plant height (Fig. 1) was reduced by approx. $35 \%$ under the influence of nickel with a content of $120 \mathrm{mg} \mathrm{kg}^{-1} \mathrm{DM}(\mathrm{C}-120)$. The plants growing at the highest concentration of nickel and simultaneously treated with UV-B (U-120) were lower by $43 \%$ than control plants (C-0). The shoot fresh mass (Fig. 2a) of the plants growing in the soil with the addition of nickel of $80 \mathrm{mg} \mathrm{kg}^{-1}$ (C-80) and $120 \mathrm{mg} \mathrm{kg}^{-1}$ (C-120) were lower by $33 \%$ and $52 \%$, respectively, as compared to the plants growing without the addition of nickel (C-0). Under the influence of UV-B (U-0), the shoot fresh mass decreased by approx. $20 \%$ compared to the control plants, and with addition of nickel in soil (U-80, U-120) - by $33 \%$ and $48 \%$, respectively. The shoot dry mass of the plants growing in the soil with the addition of nickel of $80 \mathrm{mg} \mathrm{kg}^{-1}$ and $120 \mathrm{mg} \mathrm{kg}^{-1}$ was lower by $32 \%$ and $46 \%$ respectively, as compared to the plants growing without addition of nickel. The reduction was also influenced by UV-B (Fig. 2a). The highest content of chlorophyll (Table 1) was found in the leaves of plants which were not subjected to irradiation and growing in soil without the addition of nickel (C-0). The use of UV-B irradiation and the presence of nickel reduced this feature from $5 \%$ up to $26 \%$. The intensity of $\mathrm{CO}_{2}$ assimilation $\left(\mathrm{P}_{\mathrm{N}}\right)$ decreased by more than $55 \%$ in the leaves of the plants growing in the presence of nickel in the soil at both concentrations of 80 and $120 \mathrm{mg} \mathrm{kg}^{-1}$. Ultraviolet radiation acting as a single stress factor $(\mathrm{U}-0)$ reduced the rate of net photosynthesis by $14 \%$, but this difference was insignificant. Only the simultaneous action of both stress factors (U-80) resulted in a $24 \%$ reduction in the photosynthesis rate in comparison to the control plants (C-0). The lowest value was recorded for the irradiated plants growing at the highest nickel concentration (U-120). Both stresses affected the additive. It was found that the intensity of leaf transpiration (E) under the influence of nick$\mathrm{el}$ at the concentration of 80 and $120 \mathrm{mg} \mathrm{kg}^{-1}$ was reduced by $52 \%$ and $18 \%$, respectively. The intensity of transpiration in the irradiated plants growing on a substrate with the addition of nickel $120 \mathrm{mg} \mathrm{kg}^{-1}$ (U-120) was reduced by $46 \%$ compared to the control plants. In the case of the plants treated only with UV-B irradiation (U-0) the highest content of flavonoids was found; it was higher by $25 \%$ compared to the control. In other variants of the experiment, a significant reduction in flavonoid content from $20 \%$ to $40 \%$ was observed.
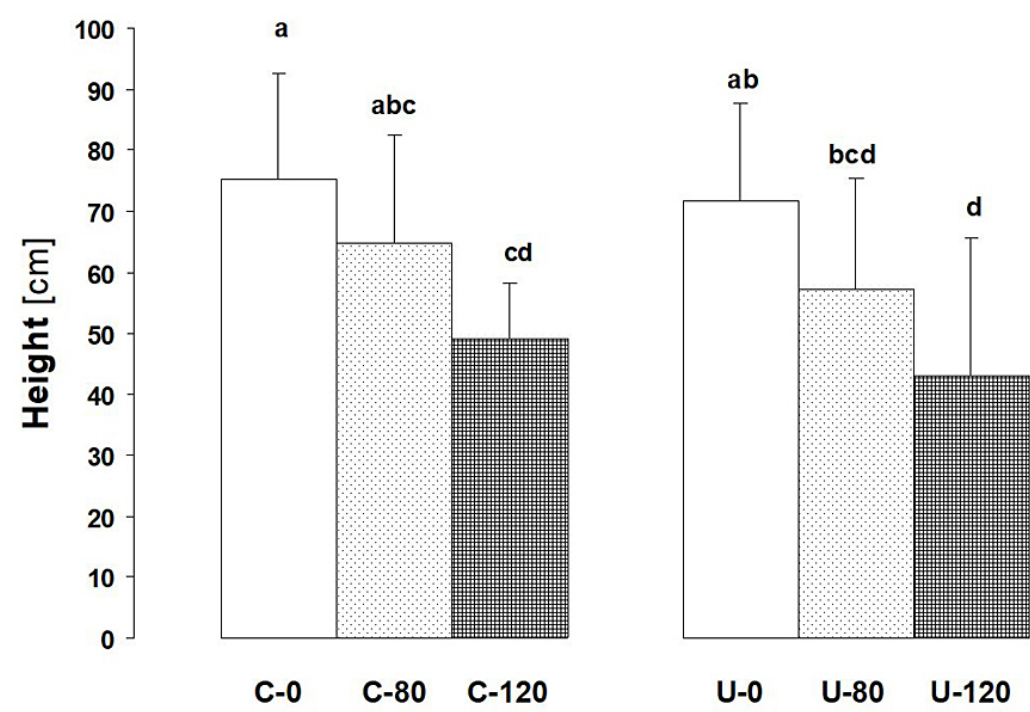

Figure 1. Height of soybean plants cultivated in presence of nickel in concentration of $80 \mathrm{mg} \mathrm{kg}^{-1}$ and $120 \mathrm{mg} \mathrm{kg}^{-1}$ (C-80, C-120) and subjected to UV-B radiation (U-80, U-120)

The control plants grew without addition $\mathrm{Ni}$ and without UV-B (C-0). The plants without addition Ni and subjected to UV-B marked 'U-0'; abc - letters denote mean values belonging to the same group; vertical segments - standard deviation 

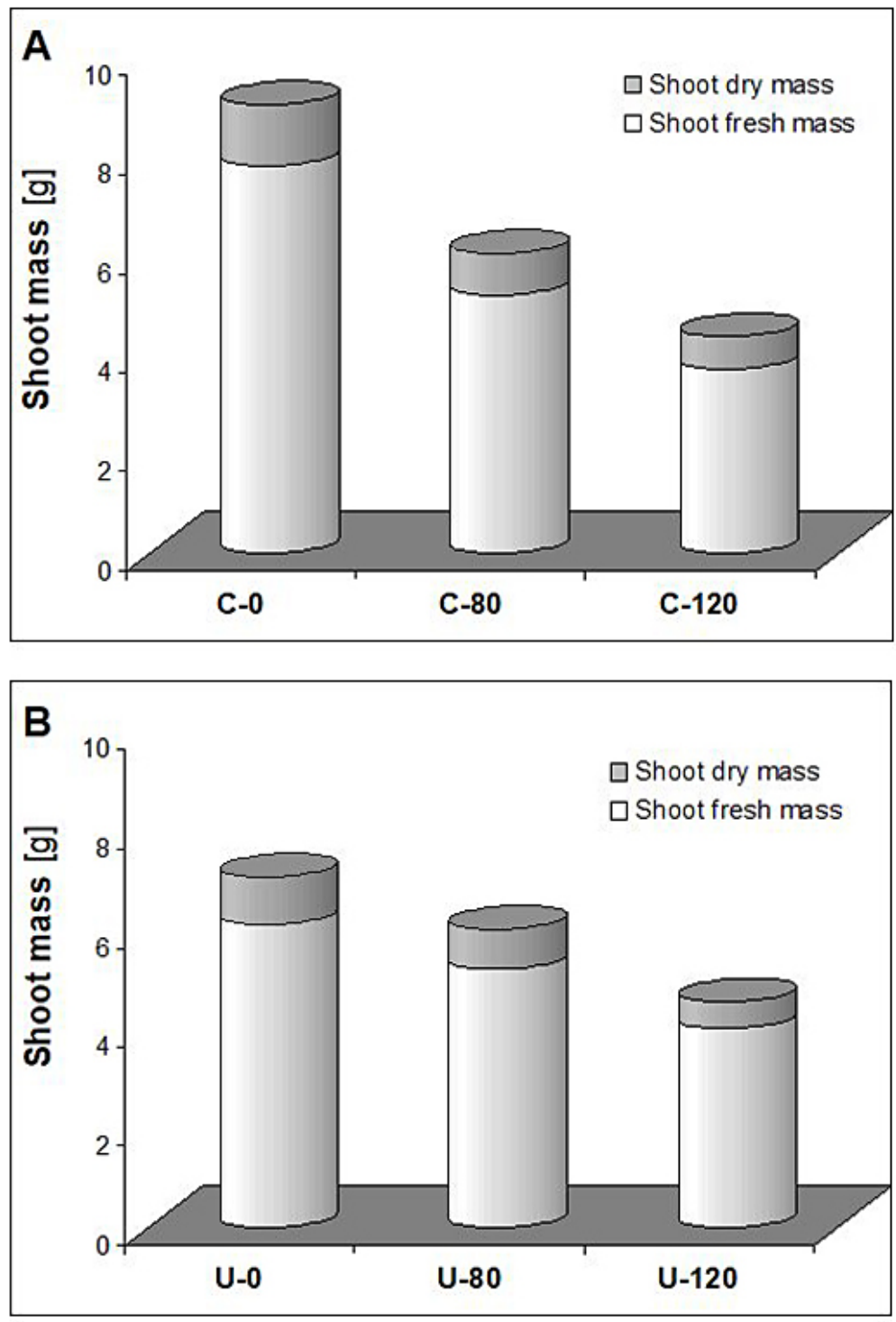

Figure 2. Fresh and dry mass of soybean plant shoot cultivated in presence of nickel in concentration of $80 \mathrm{mg} \mathrm{kg}^{-1}$ and $120 \mathrm{mg} \mathrm{kg}^{-1}$ (C-80, C-120) (A) and subjected to UV-B radiation (U-80, U-120) (B)

The control plants grew without addition Ni and without UV-B (C-0). The plants without addition Ni and subjected to UV-B marked 'U-0'.

The activity of catalase decreased in the nonUV-B plants as the concentration of nickel in the soil increased. The plants growing at the highest nickel concentration $120 \mathrm{mg} \mathrm{kg}^{-1} \mathrm{DM}$ and those not subjected to irradiation (C-120) were found to have a $38 \%$ lower catalase activity compared to control plants $(\mathrm{C}-0)$. Indeed, the catalase activity was highest in the plants irradiated and growing at a nickel concentration of $80 \mathrm{mg} \mathrm{kg}^{-1}$ (U-80). It was, respectively, $35 \%$ and $54 \%$ higher than in the plants growing at a nickel concentration of $120 \mathrm{mg} \mathrm{kg}^{-1}$ and in the irradiated plants, but without the addition of nickel in the soil (U-0). In the plants not exposed to UV-B irradiation, no significant nickel effect on peroxidase activity was observed. Only the simultaneous effect of UV-B irradiation and the presence of nickel in the soil caused changes in the peroxidase activity. In irradiated plants, peroxidase activity significantly increased along with the nickel concentration (U-80, U-120). The plants growing at the highest concentration of nickel $120 \mathrm{mg} \mathrm{kg}^{-1}$ and simultaneously exposed to UV-B (U-120) had the highest peroxidase activity compared to the other experimental variants, by $77 \%$ to the control $(\mathrm{C}-0)$. There was no influence of UV-B irradiation and nickel concentration on the chlorophyll fluorescence $\mathrm{F}_{\mathrm{v}} / \mathrm{F}_{0}$ and Rfd parameters. A small but significant 
reduction of about $10 \%$ of the $\mathrm{Y}$ was found in the leaves of soybean plants treated with UV-B and growing at a nickel content of $80 \mathrm{mg} \mathrm{kg}^{-1}$ (U-80).

\section{DISCUSSION}

The obtained results show the harmful effect of both stress factors on the growth of the investigated soybean plant cv. Augusta. Both UV-B radiation and the addition of nickel in the soil negatively influenced the height of the plant, fresh and dry mass of shoots. Our results are compatible with the data from other studies. Growth inhibition on $\mathrm{Ni}$ was also observed in soybean (Prasad et al., 2005), and also in peas (Gajewska and Skłodowska, 2005; Srivastava et al., 2012). The authors report that limiting plant growth may be the result of nickel blocking crucial physiological and biochemical processes. The simultaneous action of both studied factors exacerbates the negative impact of each factor applied separately on the height of soybean plants. The smallest height (57\% of control) and the dry mass of shoots $(44 \%)$ in our experiment characterized the plants growing at a nickel concentration of $120 \mathrm{mg} \mathrm{kg}^{-1}$ and in the presence of UV-B. Similar results were obtained by Prasad et al. (2005), who showed that a simultaneous exposure of soybean seedlings growing on a substrate containing $1 \mathrm{mM}$ nickel and UV-B irradiated with a comparable dose of $1.08 \mathrm{~kJ} \mathrm{~m}^{-2}$ resulted in a decrease in both the height of plants and their dry mass to $55 \%$ of the control. Ultraviolet radiation can indirectly influence the photosynthesis process by photodegradation of photosynthetic dyes (Jansen et al. 2008; Li et al., 2012; Hamidi-Moghaddam et al., 2019). In the conducted studies, irradiated soybean plants were characterized by a smaller green leaf index associated with a lower content of chlorophyll in leaves. A similar tendency was observed in the presence of nickel in the substrate - along with the increase in nickel concentration, the chlorophyll content was reduced. The reduced concentration of chlorophyll in the leaves of plants treated with nickel may be due to the replacement of central $\mathrm{Mg}$ with a chlorophyll molecule by Ni (Syam et al., 2016). The decrease in chlorophyll content in the plants subjected to UV-B radiation and nickel, observed in our research, was also confirmed in the literature. Nickel at a concentration of $1 \mathrm{mM}$ and UV-B applied together and separately caused a considerable decrease of chlorophyll concentration in the leaves of pea seedlings (Srivastava et al., 2012). Prasad et al. (2005) reported similar results in Glicine max L. Merr. under the influence of Ni and UV-B.

Increased nickel concentration, as a single stress factor, caused lower $\mathrm{CO}_{2}$ assimilation in soybean plants by ca $55 \%$ of the control. The application of UV-B radiation at the highest concentration of Ni $120 \mathrm{mg} \mathrm{kg}^{-1}$, decreased net photosynthesis to $31 \%$ and transpiration intensity to $53 \%$. Reis et al. (2017) also reported a decrease of the $\mathrm{CO} 2$ assimilation rates and transpiration in soybean plants growing at the Ni concentration of $20 \mu \mathrm{mol} \mathrm{dm}{ }^{-3}$. Prasad et al. (2005) found a reduction in the chlorophyll content in soybean

Table 1. The effect of nickel in soil in concentration C-0 (control), C-80 (80 mg kg-1) and C-120 (120 mg kg-1 on the physiological features without UV-B [-UV-B-] and under UV-B treatment [+UV-B]

\begin{tabular}{|c|c|c|c|c|c|c|c|c|c|c|}
\hline \multicolumn{2}{|c|}{ Variants } & SPAD & $P_{N}$ & $E$ & Flav & CAT & PRX & $F_{v} / F_{0}$ & Y & Rfd \\
\hline \multirow{3}{*}{-UV-B } & C-0 & $\begin{array}{c}36.5 \pm 2.0 \\
a\end{array}$ & $\begin{array}{c}8.13 \pm 1.10 \\
a\end{array}$ & $\begin{array}{c}1.97 \pm 0.22 \\
a\end{array}$ & $\begin{array}{c}424 \pm 35 \\
b\end{array}$ & $\begin{array}{c}33.9 \pm 0.4 \\
c\end{array}$ & $\begin{array}{c}19.1 \pm 0.7 \\
C\end{array}$ & $\begin{array}{c}2.86 \pm 0.13 \\
a\end{array}$ & $\begin{array}{c}0.57 \pm 0.02 \\
a\end{array}$ & $\begin{array}{c}1.76 \pm 0.18 \\
a\end{array}$ \\
\hline & C-80 & $\begin{array}{c}34.7 \pm 3.0 \\
b\end{array}$ & $\begin{array}{c}3.50 \pm 1.51 \\
c\end{array}$ & $\begin{array}{c}0.94 \pm 0.47 \\
c\end{array}$ & $\begin{array}{c}336 \pm 32 \\
c\end{array}$ & $\begin{array}{c}26.2 \pm 0.1 \\
d\end{array}$ & $\begin{array}{c}19.7 \pm 0.7 \\
c\end{array}$ & $\begin{array}{c}2.83 \pm 0.35 \\
a\end{array}$ & $\begin{array}{c}0.55 \pm 0.03 \\
a b\end{array}$ & $\begin{array}{c}1.53 \pm 0.12 \\
a\end{array}$ \\
\hline & C-120 & $\begin{array}{c}31.3 \pm 2.0 \\
c\end{array}$ & $\begin{array}{c}3.67 \pm 1.12 \\
c\end{array}$ & $\begin{array}{c}1.62 \pm 0.40 \\
a b\end{array}$ & $\begin{array}{c}315 \pm 14 \\
c\end{array}$ & $\begin{array}{c}21.1 \pm 0.3 \\
\mathrm{e}\end{array}$ & $\begin{array}{c}22.5 \pm 1.4 \\
c\end{array}$ & $\begin{array}{c}2.80 \pm 0.29 \\
a\end{array}$ & $\begin{array}{c}0.54 \pm 0.04 \\
a b\end{array}$ & $\begin{array}{c}1.48 \pm 0.28 \\
a\end{array}$ \\
\hline \multirow{3}{*}{$+U V-B$} & U-0 & $\begin{array}{c}32.0 \pm 1.0 \\
c\end{array}$ & $\begin{array}{c}7.02 \pm 0.32 \\
a b\end{array}$ & $\begin{array}{c}1.93 \pm 0.44 \\
a\end{array}$ & $\begin{array}{c}532 \pm 26 \\
a\end{array}$ & $\begin{array}{c}24.5 \pm 0.3 \\
d\end{array}$ & $\begin{array}{c}19.7 \pm 2.4 \\
a\end{array}$ & $\begin{array}{c}2.67 \pm 0.11 \\
a\end{array}$ & $\begin{array}{c}0.56 \pm 0.03 \\
a b\end{array}$ & $\begin{array}{c}1.55 \pm 0.21 \\
a\end{array}$ \\
\hline & U-80 & $\begin{array}{c}32.3 \pm 3.0 \\
c\end{array}$ & $\begin{array}{c}6.15 \pm 0.53 \\
b\end{array}$ & $\begin{array}{c}1.44 \pm 0.38 \\
a b c\end{array}$ & $\begin{array}{c}460 \pm 39 \\
b\end{array}$ & $\begin{array}{c}53.3 \pm 0.2 \\
a\end{array}$ & $\begin{array}{c}30.5 \pm 1.5 \\
b\end{array}$ & $\begin{array}{c}2.56 \pm 0.43 \\
a\end{array}$ & $\begin{array}{c}0.50 \pm 0.08 \\
b\end{array}$ & $\begin{array}{c}1.39 \pm 0.27 \\
a\end{array}$ \\
\hline & U-120 & $\begin{array}{c}26.9 \pm 3.0 \\
d\end{array}$ & $\begin{array}{c}2.53 \pm 1.20 \\
c\end{array}$ & $\begin{array}{c}1.05 \pm 0.78 \\
\text { bc }\end{array}$ & $\begin{array}{c}451 \pm 15 \\
b\end{array}$ & $\begin{array}{c}37.0 \pm 0.2 \\
b\end{array}$ & $\begin{array}{c}33.8 \pm 0.5 \\
a\end{array}$ & $\begin{array}{c}2.83 \pm 0.22 \\
a\end{array}$ & $\begin{array}{c}0.53 \pm 0.07 \\
a b\end{array}$ & $\begin{array}{c}1.47 \pm 0.41 \\
a\end{array}$ \\
\hline
\end{tabular}

Where: SPAD - chlorophyll content, $\mathrm{P}_{\mathrm{N}}-$ net photosynthesis intensity $\left[\mathrm{mmol} \mathrm{CO}_{2} \mathrm{~m}^{-2} \mathrm{~s}^{-1}\right] ; \mathrm{E}-$ transpiration intensity $\left[\mathrm{mmol} \mathrm{H}_{2} \mathrm{O} \mathrm{m}^{-2} \mathrm{~s}^{-1}\right]$; Flav - flavonoids content $\left[\mathrm{A}_{305} \mathrm{~g}^{-1}\right]$; CAT - catalase activity $\left[\mathrm{kU} \mathrm{g}^{-1}\right]$; PRX - peroxidase activity $\left[\mathrm{kU} \mathrm{g}^{-1}\right] ; \mathrm{F}_{\mathrm{v}} / \mathrm{F}_{0}$ - oxygen evolving efficiency; $\mathrm{Y}$ - photochemical activity of Photosystem II; Rfd - vitality index; main $\pm \mathrm{SD}$; abc - letters denote mean values belonging to the same group $(\mathrm{p}<0.05)$. 
leaves to $26 \%$ of the control and a reduction in photosystem II activity (29\% of controls). Similar changes were observed in the pea plants growing at a $1 \mathrm{mM}$ concentration of $\mathrm{Ni}$ in the substrate and UV-B treated with a dose of $1.08 \mathrm{~kJ} \mathrm{~m}^{-2}-$ the intensity of $\mathrm{CO}_{2}$ assimilation decreased to $49 \%$, electron transport in PS II to 39\% (Srivastava et al., 2012). Under the influence of UV-B radiation, the content of flavonoid compounds increased by $25 \%$ compared to the control, which is a typical defensive reaction observed by many authors in various plant species (Shen et al., 2015; $\mathrm{Li}$ et al., 2016). In our experiment, the increased concentration of Ni caused an adverse effect on the production of these compounds in soybean plants treated with UV-B radiation, as there were less of them than in the irradiated plants without the addition of Ni. In the plants not treated with UV-B growing with the addition of Ni these compounds were less than $20 \%$ compared to the control (without UV-B and without Ni). In the work on UV-B and cadmium in the substrate, Li et al. (2012) observed a reduction in the flavonoid content by about $20 \%$ under the influence of UV-B with a dose of $7.1 \mathrm{~kJ} \mathrm{~m}^{-2} \mathrm{~d}^{-1}$ and $\mathrm{Cd}$ at a concentration of $40 \mathrm{mg} \mathrm{kg}^{-1}$ on soybean plants, while without the addition of cadmium, these compounds were $20 \%$ lower than in the control.

The resistance of plants to stress factors is related to their antioxidant capacity, and increased levels of antioxidant compounds may prevent the damage caused by stress (Baroniya et al., 2013). A significant increase in the activity of antioxidant enzymes in relation to the control was observed in the plants subjected to a simultaneous exposure to UV-B and nickel irradiation. The decrease in the catalase activity and no changes in peroxidase activity were found in soybean plants cv. Augusta growing in the presence of nickel compared to the control (C-0). Prasad et al. (2005) found an increase in the catalase and peroxidase activity as a result of nickel. The soybean plants exposed only to UV-B radiation showed an increase in the catalase and peroxidase activity by $4 \%$ and $188 \%$, respectively. They also found that simultaneous UV-B radiation and nickel caused a significant decrease in the catalase activity, while peroxidase activity was still higher than in control. In contrast, Gajewska and Skłodowska (2005) did not observe any changes in the CAT activity in leaves and roots of 14 day-old pea plants treated with NiSO4 (10, 100, $200 \mathrm{mM})$ for 1, 3, 6 and 9 days. The parameters of chlorophyll fluorescence generally did not show any significant changes indicating disturbances in the functioning of the photosystem II, excluding the slight decrease of $\mathrm{Y}$ in the U-80 plants. Our previous experiments with the same long wave UV-B also showed no change in the chlorophyll fluorescence parameters on triticale (Skórska, 2000) and maize (Skórska et al., 2019). This can be explained by the fact that the soybean plants on which the measurements were made, showed a relatively high tolerance of the photosystem 2 for the applied stress factors.

\section{CONCLUSIONS}

The soybean plants under the influence of increased nickel concentration in the substrate were clearly smaller by $35 \%$, had a lower shoot mass (33-52\%), contained less chlorophyll (14\%), were characterized by lower net photosynthesis rate $(55 \%)$ and catalase activity (38\%), and contained less flavonoids (25\%). UV-B radiation applied separately did not change most of the measured features, except for the decrease of the chlorophyll content (by 12\%) and catalase activity (27\%), compared to the control (C-0). The production of flavonoids under the influence of the ultraviolet B radiation increased by $25 \%$ and was clearly lower from $20 \%$ to $40 \%$ in the plants growing at increased nickel concentration. As well as Ni and UV-B did not affect the chlorophyll fluorescence parameters depicting the functioning of the photosystem II, indicating relative high tolerance of photosystem II.

\section{REFERENCES}

1. Bandurska H., Niedziela J., Chadzinikolau T. 2013. Separate and combined responses to water deficit and UV-B radiation. Plant Science, 213, 98-105.

2. Baroniya S.S., Kataria S., Pandey G.P., Guruprasad K.N. 2013. Intraspecific variations in antioxidant defense responses and sensitivity of soybean varieties to ambient UV radiation. Acta Physiologiae Plantarum, 35, 1521-1530.

3. Bornman J.F., Barnes P.W., Robinson S.A., Ballaré C.L., Flint S.D., Caldwell M.M. 2015. Solar ultraviolet radiation and ozone depletion-driven climate change: effects on terrestrial ecosystems. Photochemistry and Photobiology Science, 14, 88-107.

4. Gajewska E., Skłodowska M. 2005. Antioxidative responses and proline level in leaves and roots of pea plants subjected to nickel stress. Acta 
Physiologiae Plantarum, 27, 329-339.

5. Guo X.Y., Zuo Y.B., Wang B.R., Li J.M., Ma Y.B. 2010. Toxicity and accumulation of copper and nickel in maize plants cropped on calcareous and acidic field soils. Plant and Soil, 333, 365-373.

6. Hamidi-Moghaddam A., Arouiee H., Nasrin Moshtaghi N., Majid Azizi M., Mahmoud Shoor M., Sefidkon F. 2019. Visual quality and morphological responses of rosemary plants to UV-B radiation and salinity stress. Journal of Ecological Engineering, 20(2), 34-43.

7. Hideg E., Jansen M.A., Strid A. 2013. UV-B exposure ROS, and stress: inseparable companions or loosely linked associates? Trends in Plant Science, 18,107-115.

8. Jansen M.A.K., Hectors K., O’Brien N.M., Guisez Y., Potters G. 2008. Plant stress and human health: Do human consumers benefit from UV-B acclimated crops? Plant Science, 175, 449-458.

9. Kabata-Pendias A., Pendias H. 2001. Trace elements in soils and plants. CRC, Boca Raton.

10. Kozlov M.V. 2005. Pollution resistance of mountain birch, Betula pubescens subsp czerepanovii, near the copper-nickel smelter: natural selection or phenotypic acclimation. Chemosphere, 59, 189-197.

11. Kutman B.Y., Kutman U.B., Cakmak I. 2014. Effects of seed nickel reserves or externally supplied nickel on the growth, nitrogen metabolites and nitrogen use efficiency of urea- or nitrate-fed soybean. Plant and Soil, 376, 261-276.

12. Li X., Zhang L., Li Y., Ma L., Bu N.C. 2012. Changes in photosynthesis, antioxidant enzymes and lipid peroxidation in soybean seedlings exposed to UV-B radiation and/or Cd. Plant and Soil, 352, 377-387.

13. Meier U. 2001. Growth stages of mono- and dicotyledonous plants. BBCH Monograph.

14. Meindl G.A., Bain D.J., Ashman T.L. 2014. Variation in nickel accumulation in leaves, reproductive organs and floral rewards in two hyperaccumulating Brassicaceae species. Plant and Soil, 383, 349-356.

15. Molas J. and Baran S. 2004. Relationship between the chemical form of nickel applied to the soil and its uptake and toxicity to barley plants (Hordeum vulgare L). Geoderma, 122, 247-255.

16. Prasad S.M., Dwivedi R., Zeeshan M. 2005. Growth, photosynthetic electron transport, and antioxidant responses of young soybean seedlings to simultaneous exposure of nickel and UV-B stress. Photosynthetica, 43, 177-185.

17. Shen X., Dong Z., Chen Y. 2015. Drought and UV-B radiation effect on photosynthesis and antioxidant parameters in soybean and maize. Acta Physiologiae Plantarum, 37, 25.

18. Skórska E. 2000. Responses of pea and triticale photosynthesis and growth to long-wave UV-B radiation. Biologia Plantarum, 43, 129-131.

19. Skórska E., Murkowski A. 2012. Comparison of susceptibility of leaves on short-term UV-B irradiation. International Agrophysics, 26, 395-400.

20. Skórska E., Grzeszczuk M., Barańska M., WójcikStopczyńska B. 2019. The long wave UV-B radiation and Asahi SL modify flavonoids content and radical scavenging activity of Zea mays var. saccharata leaves. Acta Biologia Cracoviensia series Botanica, 61, 1.

21. Srivastava G., Kumar S., Dubey G., Mishra V., Prasad S.H. 2012. Nickel and ultraviolet-B stresses induce differential growth and photosynthetic responses in Pisum sativum L seedlings. Biological Trace Element Research, 149, 86-96.

22. Syam N., Wardiyati T., Maghfoer M.D., Handayantoc E., Ibrahima B., Muchdara A. 2016. Effect of accumulator plants on growth and nickel accumulation of soybean on metal-contaminated soil. Agriculture and Agricultural Science Procedia, 9, 13-19.

23. UNEP, 2016. Environmental effects of ozone depletion and its interactions with climate change: progress report 2015 Photochemistry and Photobiology Science, 15, $141 \mathrm{pp}$.

24. Yusuf M., Fariduddin Q., Hayat S.,Ahmad A. 2011. Nickel: an overview of uptake, essentiality and toxicity in plants. Bulletin of Environmental and Contamination Toxicology, 86, 1-17. 